\title{
IDENTIFIKASI GEN PENYANDI PROTEIN TRANSPORT SEBAGAI KANDIDAT VAKSIN SUBUNIT TERHADAP BAKTERI ESCHERICHIA COLI PENYEBAB DIARE WISATAWAN
}

\author{
Burhannuddin Rasyid ${ }^{1}$, I Wayan Karta ${ }^{1}$, Ni Luh Putu Eka Kartika Sari², \\ I Gusti Ngurah Dwija Putra ${ }^{2}$ \\ ${ }^{1}$ Jurusan Teknologi Laboratorium Medis, Poltekkes Kemenkes Denpasar \\ Denpasar, Indonesia \\ ${ }^{2}$ Fakultas Kedokteran dan IImu Kesehatan Warmadewa \\ Denpasar, Indonesia \\ e-mail: boerhannuddin@gmail.com
}

\begin{abstract}
Abstrak
Penelitian ini bertujuan untuk mengisolasi dan mengkarakterisasi gen penyandi protein transport sebagai kandidat vaksin subunit terhadap E. coli penyebab diare wisatawan. Pengambilan sampel feses dilakukan di Ubud Care Clinic pada wisatawan yang melakukan pemeriksaan diare. Sampel dikultur pada media Eosin Metilen Blue, koloni tersangka kemudian diuji biokimia untuk mengkonfirmasi jenis bakteri yang ditemukan. Isolat positif E.coli selanjutnya disubkultur pada media Nutrient Broth, kemudian DNA E.coli diisolasi dengan GeneJET Genomic DNA Purification Kit. DNA hasil isolasi selanjutnya digunakan sebagai template reaksi PCR menggunakan pasangan primer yang mengenali gen aidA penyandi protein transport pada E.coli . Berdasarkan hasil kultur pada media EMB dan hasil uji biokimia pada media TSIA, SIM, Simon Citrat dan uji gula-gula didapatkan sebanyak 20 (59 \%) dari 34 sampel feses penderita diare wisatawan positif bakteri E. coli. DNA dari 20 isolat E.coli berhasil diisolasi dengan ukuran sekitar 12000-13000 bp. Hasil PCR dari 20 sampel DNA bakteri $E$. coli terdapat 5 sampel positif mengandung gen aidA yang ditunjukkan dengan adanya pita DNA tunggal dengan ukuran sekitar 585 bp. Keberadaan gen aidA yang menyandi protein transport menunjukkan sifat patogenitas, yang membedakan antara E.coli pathogen dengan E.coli non-patogen
\end{abstract}

Kata kunci: Diare Wisatawan, E.coli, Gen Protein Transport

\begin{abstract}
This study aims to isolate and determine the characteristics of the transport proteincoding gene for E.coli bacteria that cause traveler's diarrhea. Stool sampling was performed at the Ubud Care Clinic for tourists who checked diarrhea. Samples were cultured on Eosin Methylene Blue media. Suspect colonies on EMB media were tested biochemically to confirm the type of bacteria found. E.coli positive isolates were then subcultured on Nutrient Broth media, then bacterial DNA was isolated with the GeneJET Genomic DNA Purification Kit. The isolated DNA was then used as a PCR reaction template using a pair of primers that recognized the ai-dA gene of $E$. coli. Based on the culture results on the media Eosin Methylene Blue (EMB) and the results of biochemical tests on TSIA, SIM, Simon Citrate media and sugar tests were obtained as many as 20 (59\%) from 34 stool samples of diarrhea patients positive $E$. coli bacteria
\end{abstract}

Keywords: Traveler's diarrhea, E. coli, Protein Transport Gene 


\section{PENDAHULUAN}

Diare wisatawan terus menjadi masalah kesehatan yang paling sering dialami oleh wisatawan yang mengunjungi negara-negara berkembang terutama negara dengan kondisi sanitasi yang buruk (Olson et al., 2019; Steffen, 2017). Diare wisatawan ditandai dengan kondisi tinja yang tidak berbentuk sebanyak tiga kali atau lebih per hari, yang disertai dengan satu atau lebih gejala enterik seperti sakit perut atau kram. Gejala tersebut dialami oleh seseorang setelah kedatangan pada suatu wilayah dengan tujuan perjalanan wisata (Connor, 2019). Diare wisatawan me-nyebabkan morbiditas yang signifikan seperti adanya gejala sisa, hilangnya waktu per-jalanan, dan berkurangnya pendapatan bagi pelaku wisata pada negara yang dikunjungi (Riddle et al., 2017).

Prevalensi diare wisatawan dilaporkan berkisar dari $30 \%$ hingga $70 \%$, tergantung pada tujuan dan musim perjalanan yang dilakukan. Sekitar $25 \%$ wisatawan mengem-bangkan diare dalam 2 minggu pertama di luar negeri, dengan tingkat tertinggi terjadi ketika melakukan perjalanan ke Afrika dan Asia Selatan, Tengah dan Barat (Pitzurra et al., 2010). Diare wisatawan dapat terjadi segera setelah kembali dan dapat dibedakan menjadi dua kategori, yaitu akut dan persisten. Tipe akut sebagian besar disebabkan oleh bakteri dan virus patogen, biasanya ringan dan dapat sembuh tanpa pengobatan. Sedangkan tipe persisten umumnya oleh infeksi parasit seperti Giardia dan Entamoe-ba (Saussure, 2009). Praktik kebersihan yang buruk di restoran lokal kemungkinan merupakan kontributor terbesar terhadap risiko terjadinya diare wisatawan (Connor, 2019)

Tingkat kejadian diare wisatawan khususnya di Indonesia belum banyak dipub-likasikan. Hasil survey suatu studi melaporkan angka kejadian diare pada wisatawan yang mengunjungi rumah sakit di Bali adalah 5\% dari 2429 kasus diare. Masih ada kemungkinan insiden diare wisatawan meningkat jika survei dilakukan di semua klinik di Bali. Tingginya angka diare wisatawan dapat mempengaruhi jumlah kunjungan wisatawan internasional dan secara tidak langsung mempengaruhi perekonomian masyarakat setempat, terutama yang menggunakan bidang pariwisata sebagai salah satu sumber pendapatan (Ani, Suwiyoga, 2016).

Terdapat berbagai faktor yang memengaruhi kejadian diare wisatawan antara lain faktor lingkungan, host, dan agen penyebab. Kondisi lingkungan terutama hotel dan restoran, khususnya di Bali sebagai daerah tujuan utama wisata di Indonesia dilaporkan bersih tetapi untuk beberapa tempat masih belum memenuhi syarat kesehatan. Wisatawan juga cenderung mengonsumsi makanan daerah yang tidak higienis sehingga beresiko mendapatkan infeksi bakteri. Faktor host juga memengaruhi kejadian diare wisatawan seperti usia, kebiasaan makan dan minum, sosial ekonomi, negara asal, daerah yang dikunjungi, riwayat profilaksis atau persiapan lain sebelum kunjungan (Ani, Suwiyoga, 2016).

Agen penyebab diare wisatawan terutama adalah bakteri, virus, dan parasit (Steffen et al., 2015). Bakteri menjadi penyebab utama diare wisatawan dengan angka kejadian mencapai $80 \%$, sedangkan virus menyebabkan kira-kira $5 \%$ hingga $10 \%$ kasus. Statistik ini bervariasi sesuai dengan lokasi geografis, dapat naik mencapai $60 \%$ kasus jika terjadi infeksi campuran (Steffen, 2018).

Bakteri E.coli merupakan penyebab utama diare endemik dan epidemik di dunia. Secara genetik, bakteri $E$. coli bervariasi dan dapat menginfeksi jutaan orang tiap tahunnya (Tang \& Saier, 2014). E. coli dilaporkan sebagai enteropathogen yang paling banyak diisolasi dari sampel feses penderita diare wisatawan $(54,1 \%)$ di Denpasar, lebih tinggi dibandingkan jenis bakteri enterik lainnya seperti Enterobacter, Klebsiella pneumonia, dan Shigella sp. Berdasarkan type diare yang dialami wisatawan, diduga diare wisatawan tersebut disebabkan oleh Enterotoxigenic E. coli (ETEC) dan Enteroaggregative E. coli (EAEC). Kedua strain E.coli tersebut diketahui memiliki onset cepat mulai dari 8-48 jam (Masyeni et al., 2017).

ETEC) dan EAEC merupakan penyebab utama diare wisatawan yang 
secara signifikan berkontribusi juga pada mortalitas bayi (Tang \& Saier, 2014). Bakteri ini dapat mengkontaminasi makanan dan menyebabkan diare pada wisatawan. Hasil penelitian lain menunjukkan dari $40 \%$ sampel positif E.coli pada penjamah makanan, sebanyak $31,4 \%$ merupakan subtipe EAEC; $5,7 \%$ subtipe ETEC; dan 3\% memiliki kedua gen yaitu ETEC dan EAEC. Pen-jamah makanan dapat bertindak sebagai carrier berbagai penyakit infeksi seperti diare (Gitaswari \& Budayanti, 2019). Selain dua strain tersebut, tipe E.coli Enteropathogenic (EPEC), Enterohaemorrhagic (EHEC), Enteroinvasive (EIEC), dan Diffusely Adherent (DAEC) juga dapat menyebabkan diare (Tang \& Saier, 2014).

Patogenesis dari berbagai strain E.coli dipengaruhi oleh faktor virulensi seperti adhesi, injeksi protein pada sel host, mekanisme signaling, dan kolonisasi yang mengganggu respon imun, kerusakan membran sel dan manipulasi sitoskeleton. Selama tahap injeksi, E.coli mensekresikan molekul efektor pada sel host yang menggunakan satu atau lebih system sekresi protein dengan tujuan menghindari system imun atau mengubah jalur signal sel (Tang \& Saier, 2014).

Pemberian vaksin merupakan salah satu cara untuk mencegah diare yang diakibatkan infeksi bakteri E.coli, namum vaksin protektif yang luas terhadap $E$. coli patogen saat ini belum tersedia. E. coli diketahui memiliki sifat yang kompleks dan terus berkembang dari isolat nonvirulen menjadi strain yang sangat patogen (Nesta \& Pizza, 2018). Adanya peningkatan patogenitas, virulensi, dan resistensi terhadap multi-obat meningkatkan perhatian terhadap perawatan kesehatan dan membutuhkan upaya terus menerus dalam pengawasan epidemiologis dan pemantauan penyakit.

Pengetahuan yang berkembang tentang mekanisme patogenesis $E$. coli dan respon imun yang dimediasi setelah infeksi atau vaksinasi, bersama dengan kemajuan dalam teknologi "omics", membuka perspektif baru terhadap desain dan pengembangan vaksin $E$. coli yang efektif dan inovatif. Pengembangan vaksin alternatif terhadap $E$. coli penyebab diare perlu terus diupayakan dengan memperhatikan pathogenesis infeksi sehingga bisa menghasilkan proteksi yang lebih baik dengan efek samping yang kecil.

Sejumlah protein transport telah diketahui berperan dalam patogenesis diare sehingga pemahaman tentang ekspresi, lokasi, dan regulasi protein setelah infeksi penting untuk mendesain terapi (Das et al., 2018). Salah satu jenis protein transport yang berperan dalam patogenesis $E$. coli adalah protein adhesin. Protein ini berperan memediasi penempelan bakteri $E$. coli pada sel host dan merupakan salah satu mekanisme penting dalam proses infeksi. Protein adhesin merupakan faktor virulensi yang signifikan berperan dalam kolonisasi bakteri pada usus dan pembentukan biofilm. Protein adhesin dikode oleh gen aidA yang terdapat pada genom bakteri E.coli patogen. Gen aidA pertama kali diidentifikasi dan dikarakterisasi dari bakteri E.coli penyebab diare pada neonatal (Ravi, 2006).

Identifikasi gen aidA dapat dilakukan dari strain bakteri $E$. coli penyebab diare dari berbagai serotype. Gen kemudian dapat diisolasi dan dikloning menggunakan plasmid untuk dapat diekspresikan menjadi protein adhesin. Saat ini, berbagai macam protein yang dihasilkan oleh bakteri dapat dijadikan protein rekombinan dan dikembangkan sebagai kandidat vaksin sub unit. Pada penelitian ini, gen aidA yang merupakan penyandi protein adhesin diidentifikasi dan diisolasi dengan teknik Polymerase Chain Reaction (PCR). Penelitian ini merupakan tahap awal untuk pengembangan protein adhesin sebagai vaksin subunit terhadap E.coli khususnya penyebab diare wisatawan. Penelitian tentang penggunaan protein adhesin sebagai kandidat vaksin $E$. coli khususnya di Indonesia belum banyak dilakukan. Penelitian ini diharapkan membuka peluang penemuan vaksin alternatif terhadap infeksi E.coli pathogen yang berbasis protein rekombinan. 


\section{METODE Jenis Penelitian}

Jenis penelitian yang digunakan adalah penelitian deskriptif dengan mengidentifikasi bakteri E.coli penyebab diare wisatawan menggunakan metode konvensional dan molekuler berdasarkan keberadaan gen aidA pengkode protein transport.

\section{Waktu dan tempat}

Penelitian dilakukan dari bulan September 2019 - November 2019. Pengambilan sampel feses dilakukan di Ubud Care Clinic, Ubud, Gianyar pada wisatawan yang melakukan pemeriksaan diare. Identifikasi bakteri E.coli dari sampel feses dilakukan di Laboratorium Bakteriologi Jurusan Teknologi Laboratorium Medis Poltekkes Kemenkes Denpasar. Isolasi DNA dan identifikasi gen aida dengan teknik PCR dilakukan di Laboratorium Biologi Molekuler Fakultas Kedokteran dan IImu Kesehatan Universitas Warmadewa.

\section{Sampel Penelitian}

Penelitian ini menggunakan sampel feses yang diperoleh dari 34 wisatawan yang melakukan pemeriksaan diare di Ubud Care Clinic, Gianyar.

\section{Alat dan Bahan}

Alat-alat yang digunakan dalam penelitian ini yaitu biosafety cabinet (Biobase), inkubator (T01892-Esco), mesin PCR (Biometra), alat elektroforesis (Biometra), alat pembacaan UV Solo (Sientra BD), magnetic dan stirrer (Jisico), autoclave (SX-500, TOMY), oven (wagtech), micropipet 50-500 $\mu \mathrm{l}$ (Socorec), neraca analitik (Radwag), vortex, dan water bath.

Bahan-bahan yang digunakan yaitu media NB (Oxoid), tabung eppendorf, pasangan primer spesifik Aida1- $F$ ACAGTATCATATGGAGCCA dan Aida1$R$ TGTGCGCCAGAACTATTA, buffer TAE, proteinase $K$, RNAse A solution, etanol 50\%, bubuk agarosa, GenJet Genomic DNA Purification Kit (Thermo scientific), loading dye, PCR Mix, dan $\mathrm{dd}_{2} \mathrm{O}$.

\section{Prosedur Kerja}

Sampel feses dikoleksi dari 34 wisatawan yang melakukan pemeriksaan diare di Ubud Care Clinic, Gianyar. Sampel dikultur pada media selektif Eosin Metilen Blue (EMB) yang diinkubasi pada suhu 37 oC selama 24 jam. Koloni tersangka E.coli pada media EMB dikonfirmasi dengan uji biokimia pada media TSIA, SIM, simon citrat, dan gulagula dengan E.coli ATCC 25922 sebagai standar kuman. Koloni yang teridentifikasi E.coli dikultur pada media Nutrien Broth pada suhu inkubasi 37o C selama 24 jam. DNA E.coli diisolasi dari hasil kultur pada media Nutrien Broth dengan GeneJET Genomic DNA Purification Kit.

DNA E.coli hasil isolasi digunakan sebagai template untuk reaksi PCR dengan menggunakan pasangan primer gen Aida, yaitu ForwardACAGTATCATATGGAGCCA dan ReversTGTGCGCCAGAACTATTA. Reaksi PCR dilakukan dengan mencampur-kan 25 ul PCR Mix, $2 \mu \mathrm{l}$ primer Forward, $2 \mu \mathrm{l}$ primer Revers, $5 \mu \mathrm{l}$ DNA Template, dan $16 \mu \mathrm{l}$ nuclease free water. Campuran reaksi kemudian dimasukkan ke dalam mesin PCR thermo cycler dengan suhu Predenaturasi $\left(94^{\circ} \mathrm{C}, 15\right.$ menit), Denaturasi $\left(94{ }^{\circ} \mathrm{C}, 45 \mathrm{~s}\right)$, Anealing (57 ${ }^{\circ} \mathrm{C}$, 30), Ekstensi $\left(72{ }^{\circ} \mathrm{C}, 45 \mathrm{~s}\right)$, Post ekstensi ( $72{ }^{\circ} \mathrm{C}, 10$ menit) dengan 35 Siklus. Hasil PCR dielektroforesis menggunakan gel agarose $1.5 \%$ selama 45 menit, kemudian pita DNA dibaca menggunakan UV gel documentation

\section{Metode Pengumpulan Data}

Data dikumpulkan

pemeriksaan laboratorium terhadap sampel, hasil isolasi bakteri E.coli dengan metode kultur, isolasi DNA total dengan GeneJet Genomic DNA Purification Kit, dan isolasi gen aidA dengan teknik PCR.

\section{Analisis Data}

Analisis data yang digunakan dalam penelitian ini adalah analisis deskriptif, dengan menggambarkan dan mengkarakterisasi gen pengkode protein transport yang diisolasi dari bakteri E.coli penyebab diare wisatawan 


\section{HASIL DAN PEMBAHASAN \\ HASIL PENELITIAN \\ Isolasi Bakteri E.coli dari Penderita Diare Wisatawan}

Berdasarkan hasil kultur pada media Eosin Metilen Blue (EMB) dan hasil uji biokimia pada media TSIA, SIM, Simon Citrat dan uji gula-gula didapatkan sebanyak 20 (59\%) dari 34 sampel feses penderita diare wisatawan positif bakteri E.coli (Tabel 1).

Tabel 1. Hasil Pemeriksaan Bakteri E.coli dari sampel feses penderita diare

\begin{tabular}{cccc}
\hline No & Hasil Pemeriksaan & Jumlah Sampel & $\%$ \\
\hline 1 & Positif Escherichia coli & 20 & 59 \\
2 & Negatif Escherichia coli & 14 & 41 \\
\hline & TOTAL & 34 & 100 \\
\hline
\end{tabular}

Bakteri E.coli pada media Eosin Metilen Blue memilki ciri khas yaitu berwarna hijau Metalik dengan permukaan rata dan terdapat bintik hitam di tengah koloni. Hasil subkultur bakteri E.coli pada media EMB ditunjukkan pada gambar di bawah ini (Gambar 1).

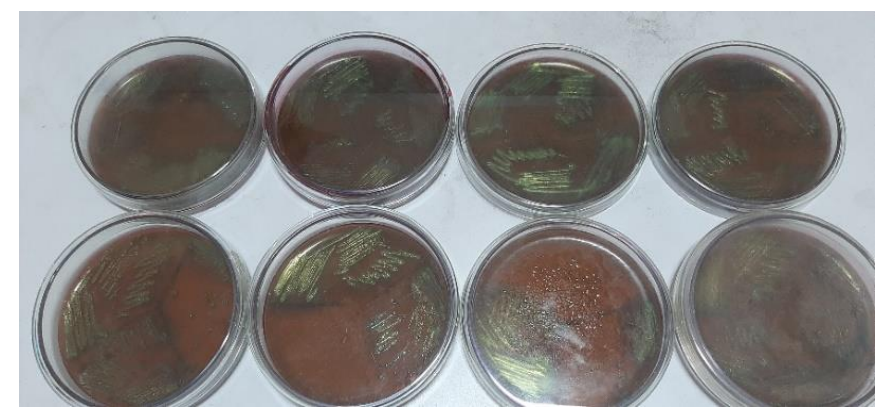

Gambar 1. Hasil isolasi Bakteri E.coli pada media EMB

\section{Hasil Isolasi DNA Bakteri Escherichia coli}

Isolat bakteri E.coli yang didapatkan sesuai hasil pemeriksaan di atas selanjutnya digunakan sebagai sumber untuk mengisolasi DNA bakteri E.coli. Masing-masing isolat diremajakan pada media Nutrient Broth selama 24 jam kemudian DNA bakteri diisolasi dengan GeneJET Genomic DNA Purification Kit. DNA dari 20 sampel E.coli penyebab diare wisatawan berhasil diisolasi dengan ukuran pita DNA sekitar 12.000-13.000 bp. Hasil isolasi DNA ditunjukkan pada Gambar 2 di bawah ini :
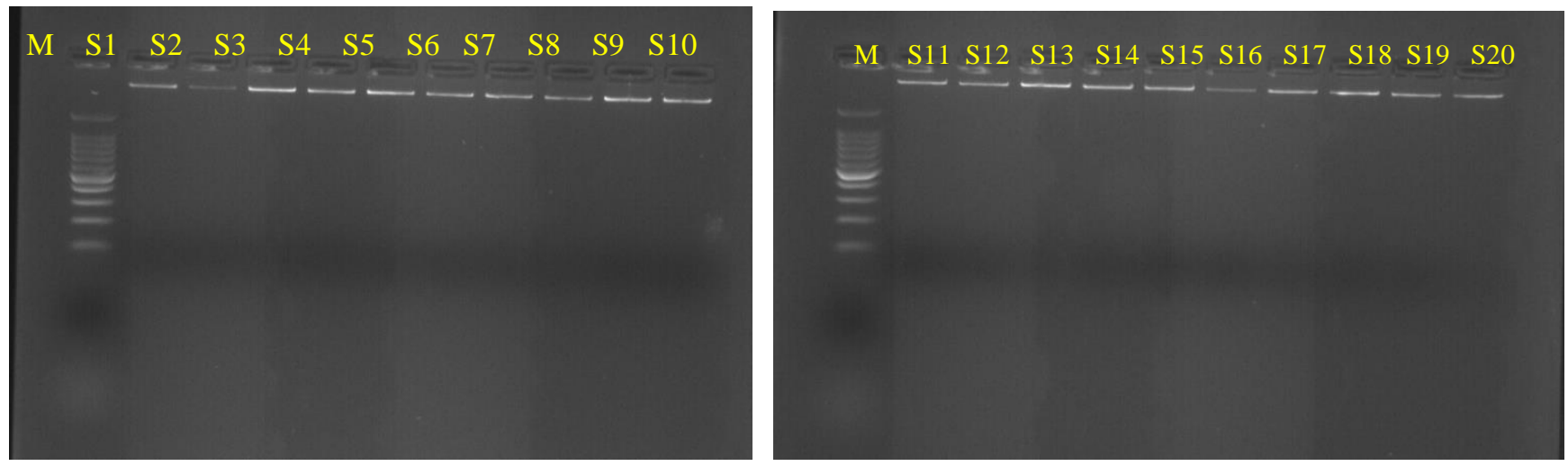

Gambar 2 Hasil isolasi DNA dari isolat bakteri Escherichia coli Ket : M (Marker 100 bp), S1-S20 (Sampel 1-20) 


\section{Hasil Amplifikasi Gen Pengkode Protein Tranport E.coli dengan Teknik PCR}

Reaksi PCR dalam penelitian ini menggunakan pasangan primer ForwardACAGTATCATATGGAGCCA dan ReversTGTGCGCCAGAACTATTA yang spesifik mengenali gen aidA pengkode protein adhesin pada bakteri E.coli. Hasil PCR menunjukkan 5 dari 20 sampel DNA E.coli penyebab diare wisatawan memiliki gen aidA pengkode protein adhesin dengan ukuran pita DNA sekitar 585 bp. Hasil PCR dari masing-masing sampel DNA $E$. coli penyebab diare wisatawan ditunjukkan pada Gambar 3 di bawah ini :
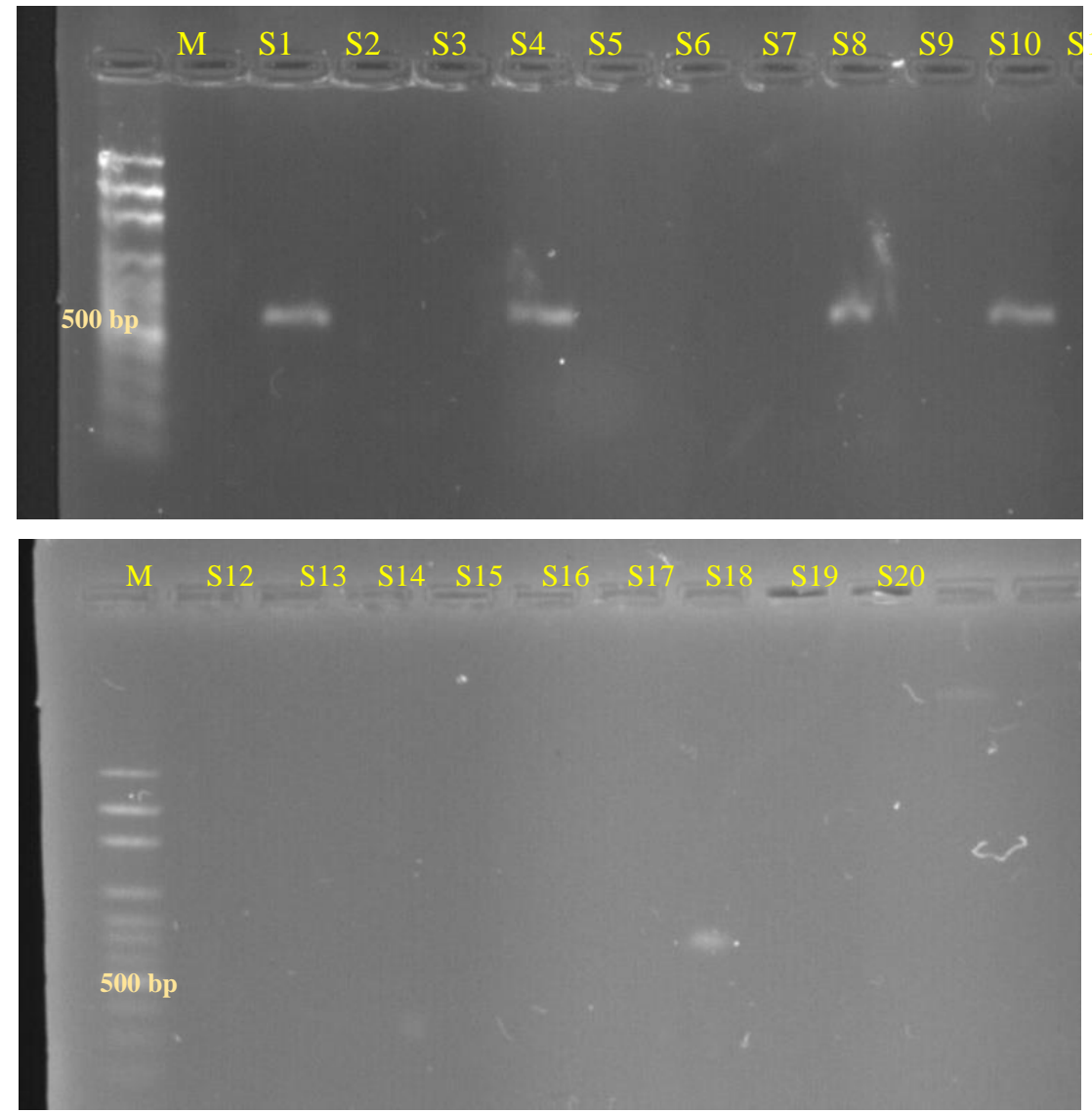

Gambar 3. Hasil PCR gen aidA pada bakteri E. coli penyebab diare wisatawan Ket : M (Marker 100 bp), S1-S20 (Sampel 1-20)

\section{PEMBAHASAN}

E. coli penyebab diare wisatawan pada penelitian ini diisolasi pada media EMB. Media EMB merupakan media selektif dan diferensial untuk menumbuhkan bakteri $E$. coli. Pada media ini, bakteri $E$. coli memfermentasi laktosa dan memproduksi asam. Suasana asam pada media menyebabkan indikator warna asam bekerja dan mengubah warna media menjadi kehijauan (Gambar 1). EMB secara selektif menumbuhkan bakteri enterik gram negatif dan menghambat pertumbuhan bakteri gram positif termasuk pertumbuhan yeast. Media ini mengandung zat pewarna metilen blue yang bersifat toksik pada mikroorganisme tersebut kecuali pada kelompok bakteri enterik. Bakteri $E$. coli pada media ini menunjukkan warna koloni yang khas yaitu hijau metalik (Antony et al., 2016). Ciri ini membedakan E. coli dengan bakteri enterik lain yang tumbuh pada media EMB. 
Koloni yang berwarna hijau metalik kemudian diuji biokimia untuk mengkonfirmasi hasil pemeriksaan yang didapatkan. Berdasarkan hasil uji biokimia yang telah dilakukan, koloni-koloni tersebut menunjukkan hasil yaitu memfermentasi ketiga gula pada media TSIA, motilitas positif, indol positif, uji pada media gula-gula (glukosa, laktosa, sukrosa, manitol, maltosa) positif, dan negatif pada uji sitrat. Hasil uji biokimia ini sesuai dengan karakteristik biokimiawi bakteri E. coli (Lupindu, 2017; Hidayati et al. 2016)

Bakteri E. coli merupakan jenis bakteri yang menjadi penyebab umum kejadian diare. Penelitian oleh Masyeni et al. (2017) mendapatkan sebanyak 54,1 \% kasus diare wisatawan di Denpasar disebabkan oleh E. coli. Hasil yang tidak jauh berbeda didapatkan pada penelitian ini, yaitu sebanyak $59 \%$ kejadian diare wisatawan di wilayah Ubud disebabkan oleh E.coli. Penelitian lain oleh Ericsson et al. (2007) menunjukkan E.coli merupakan enteropatogen yang paling sering diidentifikasi dalam kultur tinja sebelum pengobatan pada kasus diare wiatawan. Enterotoxigenic E.coli diidentifikasi pada 109 (36\%) dari 306 sampel yang diuji, dan enteroaggregative E.coli , terdeteksi dalam $50(16 \%)$ dari 306 sampel. Vila et al., (2001) sebelumnya telah melaporkan isolat Enteroaggregative E.coli sebagai penyebab diare perjalanan pada 50 (9\%) dari 517 pasien dan menunjukkan adanya peningkatan resistensi terhadap quinolone.

Bakteri E.coli penyebab diare wisatawan dalam penelitian ini merupakan jenis E.coli patogen yang dapat dibedakan dengan E.coli tipe komensal berdasarkan faktor virulensi yang dimiliki. Jenis E.coli patogen memiliki daya tahan dan berbagai faktor virulensi yang meningkatkan patogenitasnya sehingga dapat menimbulkan diare pada wisatawan. Menurut Gebisa et al. (2019) beberapa strain E.coli patogen menyebabkan penyakit diare dan dikategorikan ke dalam kelompok spesifik berdasarkan sifat virulensi, mekanisme patogenisitas, sindrom klinis, dan serogrup O:H yang berbeda. Beberapa faktor virulensi paling penting dari E.coli antara lain yaitu resistensi terhadap asam; keberadaan berbagai tipe protein adhesi seperti fimbriae, fibrillae, curli dan protein membran luar; penggunaan sistem sekresi tipe III untuk mengubah jalur pensinyalan sel dengan menyuntikkan protein yang virulen ke dalam sitoplasma sel inang seperti protein alkaline phosphatase yang dikodekan oleh gen Pho dan berbagai jenis toksin yang meningkatakan virulensi E.coli di dalam sel inang.

Selain faktor adanya virulensi E.coli yang meningkatkan kerentanan wisatawan terhadap diare, berbagai faktor lain dapat menyebabkan terjadinya diare wisatawan. Bakteri E.coli merupakan indikator sanitasi lingkungan yang dapat mengkontaminasi air, makanan, atau minuman. Wisatawan dapat mengalami intoleransi makanan atau malabsorpsi karena kebersihan makanan atau minuman yang tidak memadai (Wahyuni et al., 2019). Faktor risiko lain yang menjadi penyebab diare perjalanan pada wisatawan asing di Bali meliputi usia wisatawan, lama tinggal, dan perilaku mencuci tangan (Ani, Suwiyoga, 2016). Diare wisatawan biasanya terjadi di daerah dengan keadaan sanitasi dan higienitas masih kurang (Steffen, 2017). Wahyuni et al. (2019) dalam penelitiannya melaporkan konsumsi makanan jalanan dan makanan tradisional hasil olahan daging babi ditemukan terkait dengan kejadian diare pada wisatawan asing saat berkunjung ke Bali. Menurut Bauch and DuPon (2011) faktor genetik juga dapat memengaruhi kerentanan wisatawan terhadap diare. Individu dapat mengalami variasi kerentanan karena predisposisi genetik yang muncul akibat adanya polimorfisme nukleotida tunggal. Variasi ini mengakibatkan perbedaan dalam regulasi ekspresi protein penanda inflamasi yang terkait diare .

DNA E. coli diisolasi sebagai template untuk reaksi PCR gen aidA pengkode protein transport E.coli. DNA bakteri E.coli berhasil diisolasi yang ditunjukkan dengan adanya pita DNA tunggal pada hasil pembacaan elektroforesis gel agarosa pada Uvdoc (Gambar 2). Elektroforesis gel agarosa berperan sebagai sirkuit elektrik untuk memisahkan fragmen-fragmen DNA berdasarkan 
jumlah nukleotida penyusunnya. Semakin kecil ukuran pasang basa nukleotidanya, akan semakin mudah bermigrasi dan berada di bagian gel yang dekat dengan anoda (Radji et al., 2010). DNA pada gel agarosa akan berpendar saat disinari dengan cahaya UV karena pada gel terdapat staining gel. Senyawa ini akan berinterkalasi diantara struktur molekul asam nukleat dan menyebabkan timbulnya pendaran berupa pita DNA saat disinari UV. Setelah dibandingkan dengan marker, band yang muncul memiliki genom DNA berukuran lebih dari 10.000 bp yakni berkisar antara 12.000-13.000bp.

Isolasi DNA dengan prosedur menggunakan GenJet Genomic DNA Purification Kit dalam penelitian ini menunjukkan kualitas hasil yang cukup baik. Prosedur ekstraksi yang dikerjakan relatif lebih sederhana dan cepat dibandingkan prosedur ekstraksi standar. Pita DNA yang didapatkan berupa pita tunggal, tampak tebal dan jelas, serta tidak tampak smear yang menandakan rendahnya kontaminasi baik oleh RNA maupun protein. Kemurnian DNA yang akan digunakan sebagai template sangat penting untuk meningkatkan efisiensi saat reaksi PCR. Ammazzalorso et al. (2015) dengan kit ekstraksi DNA yang sama mendapatkan kualitas DNA paling tinggi dan hasil PCR yang konsisten dibandingkan esktraksi DNA menggunakan prosedur standar. Ravintheran et al. (2019) menggunakan prosedur ekstraksi yang sama untuk mengisolasi genom bakteri Sphingomonas paucimobilis untuk tujuan sekuensing. Sedangkan Juhas and Ajioka (2016) menggunakan prosedur ini untuk mendapatkan genom Bacillus subtilis untuk tujuan rekayasa genetika.

Reaksi PCR dalam penelitian ini menggunakan pasangan primer ForwardACAGTATCATATGGAGCCA dan ReversTGTGCGCCAGAACTATTA yang spesifik mengenali gen aidA pengkode protein adhesin pada bakteri E.coli. Hasil PCR menunjukkan 5 dari 20 sampel E.coli penyebab diare wisatawan memiliki gen aidA pengkode protein adhesin dengan ukuran pita DNA sekitar 585 bp (Gambar $3)$.
Keberadaan gen aidA pengkode protein transport pada sampel tersebut menun-jukkan sifat patogenitas, yang membedakan antara E.coli patogen dengan E.coli non-patogen. Pada E.coli patogen memiliki system sekresi yang akan melepaskan protein ke permukaan sel atau menginjeksikan suatu protein efektor ke dalam sel inang (Tang \& Saier, 2014). Beberapa strain E.coli telah dikarakterisasi sebagai agen etiologi diare baik pada anak-anak maupun orang dewasa, antara lain Enteropathogenic E.coli (EPEC), Verocytotoxigenic E.coli (VTEC), Enterotoxigenic E.coli (ETEC), Enteroaggre-gative E.coli (EAEC), Enteroinvasive E.coli (EIEC) dan Diffusely Adherent E.coli (DAEC) (Zhang et al., 2016).

Pasangan primer yang digunakan dalam reaksi PCR ini memiliki sekuen yang spesifik terhadap gen aidA pengkode protein adhesin E.coli. Gen aidA secara alami ditemukan pada strain Enteroaggregative E.coli (EAEC) O126:H127 yang menyebab-kan penyakit diare pada anak (Sherlock et al., 2004). Strain Enteroaggregative E.coli (EAEC) saat ini diketahui menjadi penyebab diare persisten pada anak, diare pada wisatawan, dan diare terkait penyakit AIDS di negara berkembang dan industri (Zhang et al., 2016).

Protein aidA merupakan salah satu type protein adhesin yang berperan dalam penempelan bakteri E.coli pada permukaan sel manusia. Protein aidA termasuk jenis auto-transporter protein yang terkait dengan faktor virulensi E.coli . Protein ini memuat semua informasi yang diperlukan untuk proses transfer molekul dalam sistem mem-bran bakteri (Sherlock et al., 2004). Protein ini juga digunakan untuk tampilan per-mukaan enzim, sebagai inhibitor enzim, antigen yang potensial untuk perkembangan vaksin, dan berbagai aplikasi lainnya (Gustavsson et al., 2011).

Pada penelitian ini gen aidA berhasil diisolasi dari DNA E.coli penyebab diare wisatawan dengan ukuran pita DNA sekitar 585 bp. Gen aidA pada penelitianpenelitian sebelumnya berhasil diidentifikasi pada E.coli penyebab diare pada ternak. Ravi, (2006) dalam 
penelitiannya berhasil mengisolasi gen aidA dari E.coli penyebab diare pada babi dengan ukuran DNA sesuai dengan hasil penelitian ini. Kanengoni et al. (2017) juga menemukan strain E.coli penyebab diare pada babi yang positif mengandung gen aidA berdasarkan hasil PCR dengan ukuran 585 bp. Torres et al. (2005) melaporkan bahwa protein aidA berperan sebagai faktor adhesi E.coli pada permukaan sel HeLa manusia. Hal ini menunjukkan bahwa gen aidA bersifat virulen dan mengekspresikan protein yang terkait dengan pathogenesis E.coli penyebab diare baik pada manusia maupun hewan ternak.

Berdasarkan hasil PCR dalam penelitian ini, terdapat 5 sampel yang mengindikasikan adanya strain E.coli patogen penyebab diare wisatawan di wilayah Ubud. Sampel E.coli dengan hasil negatif dapat berasal dari strain E.coli pathogen lainnya yang juga mampu menimbulkan diare pada wisatawan. Identifikasi lebih lanjut ter-hadap sampelsampel tersebut perlu dilakukan dengan menggunakan primer yang secara spesifik mengenali strain-strain E.coli pathogen penyebab diare wisatawan

\section{SIMPULAN \\ Kesimpulan}

$\left.\begin{array}{llllll}\text { Sebanyak } 20 & (59 & \%\end{array}\right)$ dari 34 penderita diare wisatawan di wilayah Ubud disebabkan oleh bakteri E.coli. DNA E.coli penyebab diare wisatawan berhasil diisolasi dengan ukuran pita DNA 12000-13000 bp. Hasil pemeriksaan dengan PCR didapatkan 5 isolat E.coli memiliki gen aidA pengkode protein transport dengan ukuran DNA sekitar 585 bp.

\section{Saran}

Perlu diidentifikasi lebih lanjut strain E.coli penyebab diare wisatawan dengan menggunakan primer terhadap gen-gen pengkode protein transport lainnya. Gen aidA pengkode protein transport E.coli yang didapatkan perlu dikarakterisasi lebih lanjut sebelum dilakukan kloning menggunakan plasmid yang sesuai dalam rangka pengembangannya sebagai kandidat vaksin sub-unit terhadap E.coli penyebab diare wisatawan.

\section{UCAPAN TERIMAKASIH}

Kami mengucapkan terimakasih kepada Poltekkes Kemenkes Denpasar yang mendanai penelitian ini dengan surat kontrak penelitian No. DP.02.02/PPK/5376/2019 dan atas izin menggunakan fasilitas penelitian di laboratorium Bakteriologi Jurusan Analis Kesehatan. Kami juga mengucapkan terimakasih kepada Ubud Care Clinic, Gianyar atas izin pengambilan sampel penelitian.

\section{DAFTAR PUSTAKA}

Ammazzalorso, A. D., Zolnik, C. P., \& Daniels, T. J. 2015. To beat or not to beat a tick: comparison of DNA extraction methods for ticks ( Ixodes scapularis ). PeerJ, 1-14.

Ani, L. S., \& Suwiyoga, K. 2016. Traveler 's diarrhea risk factors on foreign tourists in Denpasar Bali-Indonesia. 5(1), 152-156.

Antony, A. C., Paul, M. K., Silvester, R., Aneesa, P. A., Suresh, K., Divya, P. S., Paul, S., Fathima, P. A., \& Abdulla, M. H. 2016. Comparative Evaluation of EMB Agar and Hicrome E . coli Agar for Differentiation of Green Metallic Sheen Producing Non E . coli and Typical E . coli Colonies from Food and Environmental Samples. Journal of Pure and Aplied Microbiologu, 10(4).

Bauch, J. de la C., \& DuPon, H. L. 2011. New Developments in Traveler's Diarrhea.Gastroenterology\&Hepatol ogy, 7(2), 88-95.

Connor, B. A. 2019. Travelers' Diarrhea. In Yellow Book. National Center for Emerging and Zoonotic Infectious Diseases (NCEZID), Division of Global Migration and Quarantine (DGMQ).

https://wwwnc.colc.gov/travel/yellowb ook/2020/preparing-internationaltravelers/travelers-diarrhea.

Das, S., Jayaratne, R., \& Barrett, K. E. 2018. The Role of Ion Transporters in the Pathophysiology of Infectious Diarrhea. Cellular and Molecular Gastroenterology and Hepatology, 6(1). 
Ericsson, C. D., Ke, S. H. I., Huang, D. B., Dupont, M. W., Adachi, J. A., Cabada, F. J. D. E. L. A., Taylor, D. N., Jaini, S., \& Sandoval, F. M. (2007). Treatment of Travelers' Diarrhea: Randomized Trial Comparing Rifaximin, Rifaximin Plus Loperamide, and Loperamide Alone. CLINICAL GASTROENTEROLOGY AND HEPATOLOGY, 5, 451-456.

Gebisa, E. S., Gerasu, M. A., \& Leggese, D. T. 2019. A Review on Virulence Factors of Escherichia Coli. Animal and Veterinary Sciences. 7(3). 8393.

Gitaswari, D. A. I., \& Budayanti, S. 2019. Identifikasi Subtipe Enterotoxigenic Escherichia coli dan Enteroaggregative Escherichia coli dari Spesimen Usap Dubur Penjamah Makanan di Denpasar Menggunakan Polymerase Chain Reaction. E-Jurnal Medika Udayana. 8(1). 7-11.

Gustavsson, M., Bäcklund, E., \& Larsson, G. 2011. Optimisation of surface expression using the AIDA autotransporter. Microbial Cell Factories. 10(72). 1-10.

Juhas, M., \& Ajioka, J. W. (2016). Integrative bacterial artificial chromosomes for DNA integration into the Bacillus subtilis chromosome. Journal of Microbiological Methods. 125. 1-7.

Kanengoni, A. T., Thomas, R., Gelaw, A. K., \& Madoroba, E. 2017. Epidemiology and characterization of Escherichia coli outbreak on a pig farm in South Africa. FEMS Microbiology Letters. 364(3). 1-7.

Lupindu, A. M. 2017. Isolation and Characterization of Escherichia coli from Animals, Humans, and Environment. Licensee InTech.

Masyeni, S., Sukmawati, H., Paramasatiari, L., Aryastuti, S. A., Somia, K. A., Kambayana, G., Astika, N., Duarsa, R., \& Merati, T. P. 2017. Diarrhea Among International Travelers in Balilndonesia: Clinical and Microbiological Finding. International Journal of Travel Medicine and Global Health. 5(3). 84-88.
Nesta, B., \& Pizza, M. 2018. Vaccines Against Escherichia Coli. Curr Top Microbiol Immunol, 416, 213-242.

Olson, S., Hall, A., Riddle, M. S., \& Porter, C. K. 2019. Travelers diarrhea: update on the incidence, etiology and risk in military and similar populations - 1990-2005 versus 2005 - 2015 , does a decade make a difference? Trop Dis Travel Med Vaccines. 5(1). 1-15.

Pitzurra, R., Steffen, R., Tschopp, A., \& Mutsch, M. 2010. Diarrhoea in a large prospective cohort of European travellers to resource-limited destinations. BMC Infect Dis. 10(231). 1-9.

Radji, M., Puspaningrum, A., \& Sumiati, A. 2010. Deteksi Cepat Bakteri Escherichia coli dalam Sampel Air dengan Metode Polymerase Chain Reaction Menggunakan Primer 16E1 dan 16E2. Makara Sains. 14(1). 3943.

Ravi, M. B. 2006. Pathogenesis and clinical significance of AIDA-Ipositive $E$. coli in diarrhea of pigs. University of Saskatchewan.

Ravintheran, S. K., Sivaprakasam, S., Loke, S., Lee, S. Y., Manickam, R., Yahya, A., Croft, L., \& Millard, A. 2019. Complete genome sequence of Sphingomonas paucimobilis AIMST S2, a xenobiotic-degrading bacterium. Scientific Data, 6(280), $1-6$.

Riddle, M. S., Connor, B. A., Beeching, N. J., Dupont, H. L., Hamer, D. H., Kozarsky, P., Libman, M., Steffen, R., Taylor, D., Tribble, D. R., Vila, J., Zanger, P., \& Ericsson, C. D. 2017. Guidelines for the prevention and treatment of travelers ' diarrhea: a graded expert panel report. Journal of Travel Medicine, 24(1), 63-68.

Saussure, P. P. H. De. 2009. Management of the Returning Traveler with Diarrhea. Therap Adv Gastroenterol. 2(6). 367-375.

Sherlock, O., Schembri, M. A., Reisner, A., \& Klemm, P. 2004. Novel Roles for the AIDA Adhesin from Diarrheagenic Escherichia coli : Cell Aggregation and Biofilm Formation. 
Journal of Bacteriology. 186(23). 8058-8065.

Steffen, R. 2017. Epidemiology of Travellers' Diarrhea. Journal of Travel Medicine. 24(1). 2-5.

Steffen, R. 2018. Emerging Options for the Management of Travelers' Diarrhea. Gastroenterology \& Hepatology. 14(12).

Steffen, R., Hill, D. R., \& DuPont, R. L. 2015. Traveler's Diarrhea: A Clinical Review. JAMA. 313(1). 71-80.

Tang, F., \& Saier, M. H. 2014. Transport proteins promoting Escherichia coli pathogenesis. Microb Pathog. 4155.

Torres, A. G., Zhou, X., \& Kaper, J. B. 2005. Adherence of Diarrheagenic Escherichia coli Strains to Epithelial Cells. Infection And Immunity. 73(1).18-29.

Vila, J., Vargas, M., Ruiz, J., Espasa, M., \& Pujol, M. 2001. Susceptibility patterns of enteroaggregative Escherichia coli associated with traveller's diarrhoea : emergence of quinolone resistance. $J \mathrm{Med}$ Microbiol. 50. 996-1000.

Wahyuni, N. W. M. S., Wirawan, I. M. A., \& Hendrayana, M. A. 2019. Risks factors for diarrhea among travellers visiting Bali. Public Health and Preventive Medicine Archive (PHPMA), 7(2), 121-126.

Zhang, R., Gu, D., Huang, Y., Chan, E. W., Chen, G., \& Chen, S. 2016. Comparative genetic characterization of Enteroaggregative Escherichia coli strains recovered from clinical and non-clinical settings. Nature Publishing Group. 1-9. 